\title{
The Dynamics of Monetary and Fiscal Policy as a Tool for Economic Growth: Evidence from Nigeria
}

\author{
Samson Ogege $e^{1} \&$ Abass A. Shiro ${ }^{1}$ \\ ${ }^{1}$ Department of Finance, University of Lagos, Lagos, Nigeria \\ Correspondence: Samson Ogege, Department of Finance, University of Lagos, Lagos, Nigeria. E-mail: \\ ogegesamson@yahoo.com
}

Received: May 14, 2012 Accepted: June 15, 2012 Online Published: August 9, 2012

doi:10.5539/jms.v2n2p247 URL: http://dx.doi.org/10.5539/jms.v2n2p247

\begin{abstract}
The study investigated the dynamics of Nigeria's monetary and fiscal policies, focusing specifically on the effects on the growth of Nigerian economy. The fundamental objective is to examine the effect of monetary and fiscal policy in Nigerian economic growth. The paper employed the Engle-Granger and Johansen-Joselius method of co-integration in a VECM setting. The empirical results demonstrated that there exist a long-run linear relationship between the dependent variable and the explanatory variables, meaning that both monetary and fiscal policy contributed to the growth of Nigerian economy. Based on the above reason the paper, therefore recommended that both monetary and fiscal policy should have the same objectives at a time.
\end{abstract}

Keywords: monetary and fiscal policy, co-integration, economic growth

\section{Introduction}

Government through various agencies issues monetary and fiscal policies every year or within the year which are reasonable to take care of the activities of individual and the financial system. The appropriate task of dynamics therefore is to enable us consider questions such as where are the facts about yesterday, what will happen today as a result? In the realm of economics which this study is based on economic dynamics is the study of economic phenomena in reacting to proceeding and succeeding events.

Moreover, other branch of economics has undergone such revolutionary development in recent years as monetary and fiscal theories have recent innovations and development in advanced economics. Therefore, no systematic and integrated theory of monetary and fiscal policy is appropriate for an under developed but developing economy like that of Nigeria has not been formicated. This is however not to say that the problem of monetary and fiscal policies in developing economics have not been receiving any attention. Indeed in very recent years any individuals and agencies have been studying these problems both at the theoretical and at the administrative level. In the past in Nigeria there have been series of effort at applying these policies towards achieving economic stability.

Consequently, various tools have been employed at various times by the federal government and the Central Bank of Nigeria in the implementation of these policies. It could therefore be reasoned that non-availability of an integrated theory of monetary and fiscal policies for developing economics accounts for the dynamics nature of our policies. This article has the specific interest of examining the dynamics of monetary and fiscal policies in the economic growth and of Nigeria.

\section{Theoretical Frameworks}

The openness of the Nigerian economy as well as to exchange rate regime periods are the situations that have been assumed to exist in the analysis of this study (Adewunmi and Ojo, 1982). Olalusi (1987) notwithstanding the illusory notion that, since the Naira is not traded in the international capital or foreign market, the authorities can effect domestic monetary policy independent of whatever policy that they may implement for external sector. They also found that $60 \%$ of any Naira created or spent by the monetary authority leaked out of the economy as expenditure on imports thereby creating increase demand pressure on the foreign exchange of Nigeria. In other words, if any one Naira of government spending, 60 kobo leaked out of the economy into the external sector. The openness of the Nigerian economy, therefore works against the principle and practical aspects of the 
inconvertibility of the Naira and the ability of the monetary authorities to effect domestic and foreign trade and payment policies independently.

Olashore (1978) said that an economy is open if it trader with other nations in goods and services and is involved in international payments and relation with them no matter what form the transactions take. The extent of openness depends on the relative levels of imports and exports, exchange rates, as well as capital flow. According to them, in an open economy, foreign trade makes up a large share of domestic output and consumption. As a result there is a limited or constrained role for domestic macro-economic policy because the price level and real gross national product (GNP) depend very significantly on what happen in trading partner countries. Would inflation filters into the domestic goods that are closely competitive with import and exports. (Fisher, 1970).

Thus, openness of the economy imposes serious constraints on the conduct and the effectiveness of monetary management, seriousness of the constraint, however, depends on the type of exchange rate regime, and stem from the interdependence between the domestic economy and the rest of the world in the case of the last linkage, where a national money is inconvertible, like the Nair, the only authorized transactions of exchange are those conducted through the monetary authority and the authorized agents. The important fact is that if the economy is open all the linkage exists and has very important implications for macro-economic policies.

In the monetary model of Balance of payment (Bop), Coghlan (1981) consider an open economy maintaining a fixed exchange rate with the rest of the world and assume that money supply is adjusted to the demand for it. Price level is affected via net imports of goods and services. The consequences of the assumptions are that domestic monetary policy does not determine the domestic money supply sufficiently. By implication money supply both domestic and international reserve components, that is: $\mathrm{Ms}=\mathrm{R}+\mathrm{D}$...(1); Where $\mathrm{R}$ is international reserves; D is domestic credit and other domestic assets backing money supply. On the other hand, the money demand function (which obviously includes demand for foreign exchange in an open economy) is given by $\mathrm{Md}=$ $\mathrm{g}(\mathrm{y}, \mathrm{p}, \mathrm{c}) . .(2)$; where $\mathrm{Md}$ is nominal value of domestic money demand; $\mathrm{y}=\mathrm{y} / \mathrm{p}$ is real capital output. $\mathrm{I}=$ $r_{t} p_{e} \ldots(3)$; $I$ is nominal interest rate; $r_{t}$ is real interest rate; $p_{e}$ is expected rate of inflation at a given period. $P$ is price level (domestic), $i^{*}$ and $\mathrm{p}^{*}$ are external (nominal) interest rate and price level; international parity requires that $\mathrm{I}=\mathrm{i}^{*}, \mathrm{P}=\mathrm{p}^{*}$, since by assumption $\mathrm{Ms}=\mathrm{Md}, \mathrm{R}=\mathrm{D}$.

\subsection{The Concept of Monetary and Fiscal Policies}

Monetary policy is defined by Abel (1980) as "The management of the expansion and contraction of the volume of money in circulation for the specific purpose of achieving certain declared national objective". Anyanwu (1993) defined monetary policy as a "major economic stabilization weapon which involves measures designed to regulate and control the volume, cost, availability and direction of money and credit in an economy to achieve some specified macroeconomic policy objectives".

Nzotta (2004) also defined monetary policy to refer to the combination of discretionary measures designed to regulate and control the money supply in an economy by the monetary authorities, with a view of achieving stated or desired macro-economic goals. He also says that monetary policy is any conscious action undertaken by the monetary authorities to change or regulate the availability, quality, cost or direction of credit in any economy, in order to attain stated economic objectives. Furness (1984) in his own view sees monetary policy as "one which aim to influence economic aactiviies by variation in the supply of money in the availability of credit or interest rates". Nwankwo (1984) defines monetary policy as "The measure or a combination of measures designed to influence or regulate the volume, price and direction of money and credit to achieve nationally stipulated objectives". Ayo (1988) sees monetary policy as "deliberate action on the part of monetary authorities to control money supply and general credit availability as well as the level of cost, that is the interest rate for the achievement of certain set of economic objectives".

In 1959, the Raddiffle report saw monetary policy as having several objectives such as high stable level of employment, price stability and so on. However, it was the role of monetary policy as being of limited importance. Today, monetary policy is of primary importance in help to achieve government macro-economic objectives. The responsibility for the implementation of monetary policy is share between the central bank of Nigeria, and the Ministry of Finance both of which are agencies of the Federal Government (Diullo, 1974).

To give effect to the governments monetary policy the bank has several weapons or techniques at its disposal. These are considered in this chapter together with a survey of the role of monetary policy in recent years and the present situation. It is important to realize that monetary policy are extremely wide ranging reflecting the fact that in a modern complex economy, money is a dynamic factor capable of influencing the size of the National income, individual income, the level of aggregate demand, employment, savings, investments, the level of 
interest rates and rate of inflation all of which are factors controlling the banking system and performance (Nwankwo, 1984).

So the principal objectives of monetary policy in such a country i.e developing economy are to control credit for controlling inflation and to stabilize the price level, to stabilize the exchange ret, to achieve equilibrium in the balance of payments and to promote economic development (Jhingan 1997). Just as the important of money has been re-evaluated, the importance of monetary policy has also increased. These changes reflect a revolution in monetary theory which has been largely inspired by an American professor Milton Friedman. The beliefs that Money Matters and that monetary policy can be used to achieve government's economic growth objectives which constitute a contemporary economic doctrine, Keynesianism (Diulio, 1974).

Jhingan (1997) said fiscal policy is a powerful instrument of stabilization. By fiscal policy we refer to government actions affecting its receipts and expenditures which we ordinarily take as measured by the government's net receipts, its surplus or deficit. The government may offset undesirable variations in private consumption and investment by anticyclical variations of public expenditures and taxes.

Iyaha, Oyefusi and Oriakhi (2003) in their view saw fiscal policy to "relate to the use by government of its expenditures and taxes to influence the level of aggregate demand in the economy".

Arthur Smithies in Jhingan (1997) defines fiscal policy as a "policy under which the government uses its expenditure and revenue programmes to produce desirable effects and avoid undesirable effect on the national income, production and employment". Though the ultimate aim of fiscal policy is the long-run stabilization of the economy yet it can be only achieved by moderating short-run economic fluctuations.

In this context, Otto Eckstein in Diulio (1974) defines fiscal policy to "changes in taxes and expenditure which aim at short-run goals of full-employment and price - level stability".

Anyanwu (1993) defines fiscal policy "to that part of government policy concerning the raising of revenue through taxation and other means and deciding on the level and pattern of expenditure for the purpose of influencing economic activities". When taxation is reduced or public expenditure is increased with the aim of stimulating aggregate demand, fiscal policy is said to have been loosened. When taxation is increased or public expenditure is reduced, fiscal policy is said to have been tighted. Fiscal policy and monetary policy (which is concerned with money supply) are the two most important components of a government's overall economic policy (Umoh, 1986). In determining fiscal policy a government has to decide various things including how much to raise through direct taxes such as income tax; how much to raise through indirect taxes such as sales tax or value added tax; how much to allocate to current expenditure on such things as public sector salaries, and how much to allocate to capital expenditure on items such as hospital and road building (Ojo, 1992).

Many governments choose to spend more than they raise and so run a budget deficit. The size of the deficit is called the public sector Borrowing Requirement (PSBR), which has to be financed by printing money or by borrowing. If the money is printed there is a risk that inflation will rise if the money is borrowed, a high PSBR may lead to a rise in interest rates. (Adekanye, 1983).

Lastly, the functional finance rule, advocates that the government budget should be used to promote macroeconomic goals at all time, without regard to budget balance. In this sense, it is less concerned that the annually balanced budget with allocational and distributional considerations and more concerned with the stabilization goals (Anyanwu, 1993).

\subsection{Economic Reforms and Monetary Policy}

Direct controls, pervasive government intervention in the financial system resulting in the stifling of competition and resource misallocation, necessitated the introduction of the Structural Adjustment Programme (SAP) in 1986 SAP was a comprehensive economic restructuring programme which emphasized increased reliance on market forces. In line with this orientation, financial sector reforms were initiated to enhance competition, reduce distortion in investment decisions and evolve a sound and more efficient financial system. The reforms which focused on structural changes, monetary policy, interest rate administration and foreign exchange management, encompass both financial market liberalization and institutional building in the financial sector. The broad objectives of financial sector reform include:

Removal of controls on interest rates to increase the level of savings and improve allocative efficiency;

Elimination of non-price rationing of credit to reduce misdirected credit and increase competition;

Adoption of indirect monetary management in place of the imposition of credit ceiling on individual banks;

Enhancing of institutional structure and supervision; 
Strengthening the money and capital markets through policy changes and distress resolution measures.

\subsection{The Implication of These Reforms on Monetary Policy Is the Focus of This Section}

One of the objectives of financial reforms was to provide a liberalized and level playing field for the emergence of effective and efficient institutions that would serve as an engine of growth for the economy. Consequently, innovative institutions were encouraged to take advantage of the opportunities created by the financial liberalization policies. The structural changes in the financial sector were designed to increase competition, strengthen the supervisory role of the regulatory authorities and streamline public sector relationship with the financial sector. As part of the reform programme, operating licences for opening bank house were liberalized. Prior to 1986, Nigeria had only 40 banks, but the number increased progressively to 120 in 1992. By 1998, however, the number of banks in operation declined to 89 as a result of the liquidation of over 30 terminally distressed banks. Other types of financial institutions also increased substantially. Indeed some of these institutions, such as the discount houses and bureaux de change were not in existence before 1986. The capital base of all the financial institutions was also increased. For instance, the minimum capital requirements of banks stood at N500 million with effect from December, 1998 compared with N10 million and N6 million for commercial and merchant banks, respectively, in 1989.

\subsubsection{New Product Development}

The reforms in financial sector created certain salutary effect on the financial system. Some of such effects include improved service delivery through new innovations and product development. The use of modern technology enhanced service delivery and eliminated queues in banking halls which used to be the common feature of banks in Nigeria. Also, Automated Teller Machines (ATMs) were installed at designated points across the country to further reduce customer traffic to banks for cash withdrawals. The use of debit and credit cards was also being popularized by some banks to reduce the risk of carrying cash for transactions. Thus, the 1986 reform introduced e-money in Nigeria's banking lexicon.

\subsubsection{Shift in Monetary Policy Management}

It would be recalled that the direct approach to monetary management was the main technique of monetary policy implementation in Nigeria before the introduction of the Structural Adjustment Programme (SAP). Between 1986 and 1993, the CBN made efforts to create a new environment for the introduction of indirect approach to monetary management. A major action taken as part of the monetary reforms programme was the initial rationalization and eventual elimination of credit ceilings for selected banks that were adjudged to be sound. After the initial test run of the indirect monetary management approach, monetary management shifted to the indirect approach in which Open Market Operations (OMO) was the principal instrument of liquidity management. Since the introduction of the indirect approach, the primary and secondary markets for treasury securities have been developed to take advantage of liberalization introduced through the reforms. Discount houses, banks and recently some selected stockbrokers are now very active in the primary market for treasury bills.

\subsubsection{Interest Rate Regime}

In August, 1987 the CBN liberalized the interest rate regime and adopted the policy of fixing only its minimum rediscount rate to indicate the desired direction of interest rate. This was modified in 1989, when the CBN issued further directives on the required spreads between deposit and lending rates. In 1991, the government prescribed a maximum margin between each bank's average cost of funds and its maximum lending rates. Later, the CBN prescribed savings deposit rate and a maximum lending rate. Partial deregulation was, however, restored in 1992 when financial institutions were required to only maintain a specified spread between their average cost of funds and maximum lending rates. The removal of the maximum lending rate ceiling in 1993 saw interest rates rising to unprecedented levels in sympathy with rising inflation rate which rendered banks' high lending rates negative in real terms. In 1994, direct interest rate controls were restored. As these and other controls introduced in 1994 and 1995 had negative economic effects, total deregulation of interest rates was again adopted in October, 1996.

\subsubsection{The Payment System}

The Nigerian payments underwent substantial modernization of the process for handling payments with the implementation of the Magnetic Ink Character Recognition (MICR), which involved the phased adoption of MICR technology for processing of inter-bank transfer and in-house cheques. This was followed by the establishment of Automated Teller Machine (ATMs) by most banks for cash dispensing, account balance enquiry and payment of utility cheques. The ATMs in addition provided the basis for setting up electronic links to on-line customers and other accounts system among bank branch network to facilitate payments service. To 
further improve the efficiency of the payment system, the CBN in 2004 issued the broad guidelines on electronic banking (e-banking). E-banking practice in Nigeria will continue to be promoted in line with global trend. The Bank will continue to encourage banks to install ATM machines for cash withdrawals. Also, in order to encourage the use of electronic money (e-money), in line with international best practices, the Bank continues to issue specific guidelines on standards and use of e-money products such as credit cards, debit cards, digital cash etc. With the recent revolution in the telecommunication sector, the environment for efficient e-banking service delivery has been laid (CBN, 2011).

The CBN has continued to promote the automation of the payments system to reduce delays in the clearing of payment instruments; reduce cash transactions; and enhance the transmission mechanism of monetary policy. In order to deal with large-value payments and settlements, the CBN has embarked on the implementation of Real Time Gross Settlement (RTGS) system. The RTGS will eliminate the risk in large-value payment, and increase the efficiency of the payment system (CBN, 2011).

\section{Methodology}

The model to be used for this research work is sensitive to measures the long run relationship between monetary and fiscal policy and gross domestic product. The reason for the choice of this model is that it is all encompassing which will involve all monetary and fiscal indicators. The data for the study are sourced from CBN statistical bulletin various issues, which range from 1970- 2010.

$$
Y_{t}=\beta+\alpha_{1} Y_{t-1}+\alpha_{2} Y_{t-2}+\alpha_{p} Y_{t-p}+U_{t}
$$

where $U_{t}$ is a white noise disturbances term. Hence equation(1) can take this shape.

$$
Y_{t}=B+\sum \alpha_{1} Y_{t-1}+U_{t}
$$

Where $\mathrm{b}$ is a constant and $\alpha_{1} \ldots \alpha_{\mathrm{p}}$ are parameters of the model

$$
\sum_{i=1}^{p} Y_{t}=B+\alpha L_{i} Y_{t} U_{t}
$$

As $\log$ operator

$$
A(L)=\left(1-\alpha_{1} L_{1}-\alpha_{2} L_{2} \ldots \ldots \ldots \ldots . . \alpha_{p} L_{p}\right)
$$

If $\mathrm{U}_{\mathrm{t}}$ is a white noise process with $\mathrm{E}\left(\mathrm{U}_{\mathrm{t}}\right)=0$ and $\mathrm{V}$ at $\left(\mathrm{U}_{\mathrm{t}}\right)=\theta^{2}$

$$
\begin{gathered}
Y_{t}=B+U_{t}+\alpha_{l} U_{t-1}+\alpha_{2} U_{t-2}+\ldots+\alpha_{q} U_{t-q} \\
Y_{t}=B+\sum_{i=1}^{q} \alpha_{l} U_{t-1}+U_{t}
\end{gathered}
$$

A linear combination of white noise process such that $\mathrm{Yt}$ is a function of current and lagged values of a white noise disturbance process (Brook, 2008). Equation can be rewritten with the lag operation notation.

$$
\begin{gathered}
Y_{t}=B+\sum_{i=1}^{q} \alpha L^{i} U_{t}+U_{t} \\
Y_{t}=B+\alpha_{1} Y_{t-1}+\alpha_{2} Y_{t-2}+\ldots \alpha_{p} Y_{t-p}+\alpha_{1} U_{t-1}+\alpha_{2} U_{t-2}+\ldots \alpha_{q} U_{t-q}+U_{t}
\end{gathered}
$$

Where $\mathrm{E}\left(\mathrm{U}_{\mathrm{t}}=0\right) ; \mathrm{E}\left(\mathrm{U}_{\mathrm{t}}^{2}\right)=\theta^{2} ; \mathrm{E}\left(\mathrm{U}_{\mathrm{t}} \mathrm{U}_{\mathrm{s}}\right)=0, \mathrm{t} \neq \mathrm{s}$.

Stationarity in a time series data is a desirable property for an estimate AR model. This is because a model whose co-efficients are non-stationary will have non-declining effects on the current values of the dependent variable as time progress which is counter-productive, empirically defective and could lead to spurious regressions. In this stating, the Augmented Dickey-fuller (ADF) and Philips-Perron (PP) unit root test are employed to handle the problem of data stationarity.

$$
Y_{t}=B+\alpha Y_{t-1}+U_{t}
$$

Where $\mathrm{B}$ and $\alpha$ are parameter of the model and $\mathrm{Ut}$ is a white noise disturbance term.

If and only if, $-1 \leqq \alpha \geqq 1$, then $\alpha=1$, then $Y_{\mathrm{t}}$ is a non-stationary series.

$$
\Delta Y=B+R Y_{t-1}+U_{t}
$$

Where $\mathrm{R}=(\alpha-1)$ and the null hypothesis can be tested as

$\mathrm{H}_{0}: \mathrm{R}=0$

$$
\Delta Y_{t}=B+R Y_{t-1}+\sum_{i=1}^{p} \Delta Y_{t-1}+U_{t}
$$

Therefore in order to be sure that the problem of errors uncorrelated the lagged term are included.

The study also adopted Engle and Granger (1987) co-integration.

$$
Y_{t}=B_{o}+B_{i} X_{t}+U_{t}
$$




$$
U_{t}=Y_{t}-B_{o}-B_{i} X_{t}
$$

In addition to determine the direction of causality between the variables, the study employ the Granger causality test;

$$
\begin{array}{ll}
Y_{t}=B_{o}+\sum_{i=1}^{n} B_{i} Y, & Y_{t-1} \sum_{i=l}^{n} X_{t-1} B X+U_{t} \\
\mathrm{X}_{\mathrm{t}}=\alpha_{\mathrm{o}}+\sum_{\mathrm{i}=1}^{\mathrm{n}} \alpha_{\mathrm{i}} \mathrm{Y} & \mathrm{Y}_{\mathrm{t}-1} \sum_{\mathrm{i}=1}^{\mathrm{n}} \mathrm{XB}_{\mathrm{i}} \mathrm{X}+\mathrm{Y}_{\mathrm{t}}
\end{array}
$$

Where $\mathrm{X}_{\mathrm{t}}$ and $\mathrm{Y}_{\mathrm{t}}$ are the variables to be tested and $\mathrm{U}_{\mathrm{t}}$ and $\mathrm{V}_{\mathrm{t}}$ are white noise disturbance terms.

The model:

$$
\begin{gathered}
\text { Real } G D P=F(L R, T B R, T R, G E, O P E N, P O L) \\
R G D P=\alpha_{o}+\alpha_{1} L R+\alpha_{2} T B R+\alpha_{3} T R+\alpha_{4} G E+\alpha_{5} O P E N+\alpha_{6} P O L+U_{t}
\end{gathered}
$$

Where

RGDP $=$ Real Gross Domestic Product

$\mathrm{LR}=$ lending rate

$\mathrm{TBR}=$ Treasury bill rate

$\mathrm{TR}=\operatorname{tax}$ Tax rate

$\mathrm{GE}=$ Government expenditure

OPEN $=$ Exports plus imports as a ratio of GDP

$\mathrm{POL}=$ Political Stability

$\mathrm{U}_{\mathrm{t}}=$ Stochastic error term.

From the table (2), $\mathrm{R}^{2}$ is $99.37 \%$ while the adjusted $\mathrm{R}^{2}$ is $99.17 \%$ showing that $99.37 \%$ of the variation ion lnRGDP can be explained by changes in the explanatory variables. The explanatory variables $\operatorname{logGN}$ (Government expenditure), logOPEN (degree of openness of economy) and logPOL (degree of government regulation rate), are significant at 5\% level of significance, while logLR (lending rate) and logTBR (treasury bill rate) are significant at $10 \%$ and the rest are not. With respect to the signs and sizes of the parameter estimates, only VT and sizes of all the other independent variables are in consonance with theoretical expectation.

Furthermore the overall fit of the model is good given an F-statistics of 492.7898 (P-value $=0.0000$ ). However, the DW-statistics is found to be 1.886 which is higher than the adjusted $\mathrm{R}^{2}$ value of 0.9917 and lies between the

\begin{tabular}{|c|c|c|c|c|}
\hline Variable & Coefficient & Std. Error & t-Statistic & Prob. \\
\hline $\mathrm{C}$ & 3.570437 & 2.758538 & 1.290697 & 0.2074 \\
\hline LogLR & 0.74412 & 0.380947 & 1.849892 & 0.0749 \\
\hline $\log T R$ & 0.438375 & 0.330659 & 2.325759 & 0.0195 \\
\hline LogGE & 0.233831 & 0.076796 & 3.044820 & 0.0050 \\
\hline LogTBR & -0.603713 & 0.343058 & -1.759799 & 0.0894 \\
\hline $\log \mathrm{OPEN}$ & -0.414585 & 0.121929 & -3.400206 & 0.0020 \\
\hline LogPOL & -1.173179 & 0.318384 & -3.684793 & 0.0010 \\
\hline R-squared & 0.993726 & Mean dependent var & 5.933368 & \\
\hline Adjusted R-squared & 0.991710 & S.D dependent var & 2.440057 & \\
\hline S.E of regression & 0.222168 & Akaike info criterion & 0.050171 & \\
\hline Sum squared resid & 1.382045 & Schwaz criterion & & 0.481115 \\
\hline Log likelihood & 9.046750 & F-statistic & & 492.7898 \\
\hline Durbin-Watson stat. & 1.885730 & Probability (F-stat.) & & 0.000000 \\
\hline
\end{tabular}
$\mathrm{D}-\mathrm{W}$ critical values of 1and 2, suggesting the presence of some degree of positive autocorrelation in the level series. This indicates that there may be some degree of time dependence in the level series which could lead to spurious regression results, suggesting the need for more rigorous analysis of the stationarity of level series data.

Table 1. Level series OLAS multiple regression summary results

Note: Dependent Variable: $\operatorname{logRGDP}$. Method: Least Squares.

Source: Authors' computation (2012) 
In view of the time dependent feature of our data, the variables were tested for unit root using both the ADF and PP tests at the level, first difference and second difference series. The results of the unit root tests are presented in Table below.

Table 2. Testing for unit root

\begin{tabular}{llll}
\hline Variables & ADFTest: 1st Diff. statistics & PP Test: Ist Diff. Statitics & Order of integration \\
\hline LogRGDP & -6.909437 & -13.18082 & $1(1)$ \\
LogLR & -5.409861 & -8.277836 & $1(1)$ \\
LogTBR & -8.547662 & -16.17624 & $1(1)$ \\
LogGE & -7.173717 & -18.42792 & $1(1)$ \\
LogTR & -7.772326 & -16.57801 & $1(1)$ \\
LogOPEN & -7.511231 & -18.30047 & $1(1)$ \\
LogPOL & -6.928203 & -13.29821 & $1(1)$ \\
RESID & -9.450283 & -18.66942 & $1(1)$ \\
\hline
\end{tabular}

Critical Values: (ADF): $1 \%-3.6289 ; 5 \%-2.9472 ; 10 \%-2.6718$

(Phillips-Perron): $1 \%-3.6228 ; 5 \%-2.9446 ; 10 \%-2.6105$

Source: Authors' computation (2012)

Table 2 above presents the summary results of both the ADF and PP unit root tests. The result of the unit root tests show that the null hypothesis of a unit root test for first difference series for all the variables can be rejected at all the critical values indicating that the level series which is largely time-dependent and non-stationary at the first difference and maximum lag of one. Thus, the reduced from model follows an integrating order of 1(1) process and is therefore a stationary process. From table above also, the test of stationarity in the residuals from the level series regression is significant at all lags.

\subsection{Co-integration Test}

Applying the Johansen co-integration test, we find that the null hypothesis of no co-integration is rejected and we conclude that the variables are co-integrated in the long run. To determine the number of co-integrating equations, we employ the Johansen (1991) test for co-integrating vectors in a VAR system. The test assumption as shown in table 3 below is linear deterministic trend in the data lag interval of 1 to 1 .

Table 3. Johansen co-integration test

\begin{tabular}{lllll}
\hline Eigevalue & Likelihood Ratio & $5 \%$ critical value & $1 \%$ critical value & Hypothesis No. of CE(s) \\
\hline 0.981655 & 506.5345 & 233.13 & 247.18 & None** \\
0.879482 & 261.4899 & 156.00 & 168.36 & At most $2^{* *}$ \\
0.821014 & 189.5475 & 124.24 & 133.57 & At most $3^{* *}$ \\
0.780599 & 131.0523 & 94.15 & 103.18 & At most $4^{* *}$ \\
0.646830 & 79.47932 & 68.52 & 76.07 & At most 5** \\
0.421980 & 44.09197 & 47.21 & 54.46 & At most 6 \\
0.289004 & 12.02115 & 15.41 & 20.04 & At most 7 \\
0.012397 & 0.424145 & 3.76 & 6.65 & At most 8 \\
\hline
\end{tabular}

Note: Test assumption: Linear deterministic trend in the data

Sample: $1970-2010$

Included observations: 40

Series: $\log$ (RGDP) $\log (\mathrm{LR}) \log (\mathrm{TR}) \log (\mathrm{GE}) \log (\mathrm{TBR}) \log (\mathrm{OPEN}) \log (\mathrm{POL})$

Lags interval: 2 to 2

*(**) denotes rejection of the hypothesis at $5 \%(1 \%)$ significant level

L.R test indicates 6 co-integrating equations at $5 \%$ significant level 
Table 3 above shows the results of the Johansen co-integration test. The null hypothesis of at most 5 co-integrating equations is rejected at $5 \%$ level of significance and hence the alternative hypothesis of at most 6 co-integrating equations at the $5 \%$ level of significance is accepted. This implies that there are 6 linear combinations of the variables that are stationary in long run.

\section{ERROR CORRECTION MODEL (ECM)}

To further the analysis of the long run relationship, the monetary and fiscal policy-growth model under investigation is then specified in a VECM incorporating a two-period lagged residual. The VECM is employed to capture the short-run deviations of the parameters from the long run equilibrium. The autoregressive distributed lag technique was used with a maximum lag of 1 to obtain an over-parameterized result (table 4) and then arriving at the parsimonious error correction result using the general-specific approach as presented in table 5 .

Table 4. Over-parameterized result

\begin{tabular}{|c|c|c|c|c|}
\hline Variable & Coefficient & Std. Error & t-Statistic & Prob. \\
\hline $\mathrm{C}$ & -0.005854 & 0.030685 & -0.190793 & 0.8522 \\
\hline $\mathrm{D}(\log (\operatorname{RGDP}(-1)))$ & -0.312107 & 0.208813 & -1.494670 & 0.1631 \\
\hline $\mathrm{D}(\log (\mathrm{POL})))$ & -1.823699 & 0.472870 & -3.856661 & $0.0027^{*}$ \\
\hline $\mathrm{D}(\log \mathrm{POL}((-1)))$ & -0.769175 & 0.358770 & -2.143922 & $0.0552 * *$ \\
\hline $\mathrm{D}(\log (\mathrm{OPEN})))$ & -0.392777 & 0.185573 & -2.116561 & $0.00579 * *$ \\
\hline $\mathrm{D}(\log (\mathrm{OPEN}(-1)))$ & -0.033600 & 0.129880 & -0.258700 & 0.8006 \\
\hline $\mathrm{D}(\log (\mathrm{LR})))$ & -0.199161 & 0.239905 & -0.830167 & 0.4241 \\
\hline $\mathrm{D}(\log (\mathrm{LR}(-1)))$ & -0.231023 & 0.539318 & -0.428361 & 0.6767 \\
\hline $\mathrm{D}(\log (\mathrm{TR})))$ & 0.039202 & 0.234434 & 0.167218 & 0.8702 \\
\hline $\mathrm{D}(\log (\mathrm{TR}(-1)))$ & 0.170705 & 0.331809 & -2.514468 & 0.6171 \\
\hline $\mathrm{D}(\log (\mathrm{GE})))$ & 0.063621 & 0.066071 & 0.962915 & $0.0535+$ \\
\hline $\mathrm{D}(\log (\mathrm{GE}(-1)))$ & 0.026474 & 0.063015 & 0.420117 & 0.6825 \\
\hline $\mathrm{D}(\log (\mathrm{TBR})))$ & 0.037198 & 0.257857 & 0.144258 & 0.8879 \\
\hline $\mathrm{D}(\log (\mathrm{TBR}(-1)))$ & 0.315051 & 0.372870 & 0.844935 & 0.0416 \\
\hline $\operatorname{ECM}(-2)$ & -0.246881 & 0.354527 & -0.696367 & $0.5006^{* *}$ \\
\hline R-squared & & \multicolumn{3}{|c|}{ Mean depedent var } \\
\hline 0.885150 & & \multicolumn{3}{|c|}{0.007523} \\
\hline Adjusted R-squared & & \multicolumn{3}{|c|}{ S.D depedent var } \\
\hline 0.676332 & & \multicolumn{3}{|c|}{0.287672} \\
\hline S.E of regression & & \multicolumn{3}{|c|}{ Akaike info criterion } \\
\hline 0.163662 & & \multicolumn{3}{|c|}{0.537370} \\
\hline Sum squared resid & & \multicolumn{3}{|c|}{ Schwarz criterion } \\
\hline 0.294637 & & \multicolumn{3}{|c|}{0.424519} \\
\hline Log likelihood & & \multicolumn{3}{|l|}{ F-statistic } \\
\hline 29.59792 & & \multicolumn{3}{|l|}{4.238864} \\
\hline Durbin-Watson stat & & \multicolumn{3}{|c|}{ Prob(F-statistic) } \\
\hline 2.010799 & & \multicolumn{3}{|c|}{0.008741} \\
\hline
\end{tabular}

Note: Dependent Variable: D(D(lnRGDP))

Method: Least Squares

Sample(adjusted): 1973-2010

Included observations: 37

Excluded observation: 3 after adjusting endpoints.

$*(* *)$ significant at $5 \%(10 \%)$

The parsimonious error correction result indicates a good fit with an F-ratio of 5.4606, an R2 of $72.31 \%$ and an adjusted R2 of $59.07 \%$, meaning that the model explains approximately $72.31 \%$ of the variations in RGDP. In addition, the one- period lag of TBR and TR exert positive and significant impact on economic growth (RGDP) 
in the model, while the one-period lag of RGDP, POL,(as well as POL unlagged) exert negative and significant influence on RGDP. The D-W statistic is approximately 2.00 and shows absence of autocorrelation.

Table 5. Parsimonious error correction result

\begin{tabular}{lllll}
\hline Variable & Coefficient & Std. Error & t-Statistic & Prob. \\
\hline $\mathrm{C}$ & 0.015596 & 0.031140 & 0.500822 & 0.6213 \\
$\mathrm{D}(\operatorname{Iog}(\mathrm{RGDP}(-1)))$ & -0.562467 & 0.142630 & -3.943539 & $0.0006^{*}$ \\
$\mathrm{D}(\operatorname{Iog}(\mathrm{POL}(-1)))$ & -0.861583 & 0.310343 & -2.776232 & $0.0107^{*}$ \\
$\mathrm{D}(\operatorname{Iog}(\mathrm{POL}(-1)))$ & -0.702870 & 0.242973 & -2.892790 & $0.0082^{*}$ \\
$\mathrm{D}(\operatorname{Iog}(\mathrm{OPEN})))$ & -0.119907 & 0.077189 & -1.553418 & 0.1340 \\
$\mathrm{D}(\operatorname{Iog}(\mathrm{LR})))$ & -0.128479 & 0.100797 & -1.274631 & 0.2152 \\
$\mathrm{D}(\operatorname{Iog}(\mathrm{TR}(-1)))$ & -0.151253 & 0.076893 & -1.967071 & $0.0614^{* *}$ \\
$\mathrm{D}(\operatorname{Iog}(\mathrm{TBR}(-1)))$ & 0.198733 & 0.090657 & 2.192139 & $0.0388^{*}$ \\
ECM(-2) & -0.478747 & 0.248325 & -1.927903 & $0.0663^{* *}$ \\
R-squared & 0.723114 & Mean dependent var & 0.005358 \\
Adjusted R-squared & 0.590690 & S. D. dependent var & 0.282967 \\
S. E. of regression & 0.180971 & Akaike info criterion & -0.315099 \\
Sum squared resid & 0.753262 & Schwarz criterion & 0.218163 \\
Long likelihood & 17.51423 & F-statistic & 5.460598 \\
Durbin-Watson stat & 1.990834 & Prob(F-statistic) & 0.000302 \\
\hline
\end{tabular}

Note: Dependent Variable: D(In(RGDP))

Method: Least Squares

Sample (adjusted): 1973-2010

Included observations: 37

Executed observations: 1 after adjusting endpoints

$*(* *)$ sig. at $5 \%(10 \%)$

Source: Author's Computation

The error correction term (ECM) is low, has the appropriate negative sign and shows that approximately $47.9 \%$ of the deviation from the long-run equilibrium in the monetary and fiscal policy-growth model is corrected bi-annually by the dynamics in the monetary and fiscal policy.

\subsection{Pair Wise Causality Test}

Pairwise Granger causality tests were run on the model with at all optimal lag or I. The results are as presented in Tables 7A and 7B below. The researcher's interest here is to establish the direction of causality between monetary and fiscal policy indicators (LR, TR, GE, TBR) and GDP as well as using their natural log transform.

The results show that the F-statistic for the null hypothesis of the causality test running from InMC to InRGDP is 1.38600 with a P-value of 0.24703 and from InRGDP> to InLR, the F-statistic is 9.18796 and P-value is 0.00456 indicating a uni-directional causality from InRGDP to InLR at 5\% level of significance. The results also show causality running significantly and uni-directionally from IogTR to IogRGDP; from IogRGDP to IogGE and finally from IogRGDP to IogTBR. On the other hand, using the unlagged values of the variables, causality runs predominantly from RGDP to LR and TBR respectively and from GE only to GDP. 
Table 6a. Pairwise granger causality test results

\begin{tabular}{llll}
\hline Null Hypothesis: & Obs & F-Statistic & Probability \\
\hline Iog(LR) does not Granger Cause IogRGDP & 40 & 1.38600 & 0.24703 \\
Iog(RGDP) does not Granger Cause Log(LR) & & 9.18796 & $0.00456^{*}$ \\
Iog(TR) does not Granger Cause IogRGDP & 40 & 7.18211 & $0.01115^{*}$ \\
Iog(RGDP) does not Granger Cause Iog(TR) & & 0.74602 & 0.39362 \\
Iog(GE) does not Granger Cause IogRGDP & 40 & 2.17678 & 0.14959 \\
Iog(RGDP) does not Granger Cause Iog(GE) & & 5.48770 & 0.02533 \\
Iog(TBR) does not Granger Cause IogRGDP & 40 & 1.51039 & 0.22728 \\
Iog(RGDP) does not Granger Cause log(TBR) & & 5.46641 & $0.02523^{*}$ \\
\hline
\end{tabular}

Note: Sample: 1970 - 2008: (IogRGDP, IogLR, IogTR, IogGE, IogTBR)

Lags: 1

*sig. at $5 \%$

Source : Author's Computation

Table 6b. Pairwise granger causality test results

\begin{tabular}{llll}
\hline Null Hypothesis: & Obs & F-Statistic & Probability \\
\hline LR does not Granger Cause RGDP & 40 & 0.96986 & 0.33147 \\
RGDP does not Granger Cause LR & & 40.4204 & $0.00000^{*}$ \\
TR does not Granger Cause RGDP & 40 & 0.08814 & 0.76831 \\
RGDP does not Granger Cause TR & & 0.12700 & 0.72370 \\
GE does not Granger Cause RGDP & 40 & 4.83583 & 0.03457 \\
RGDP does not Granger Cause GE & & 37.1926 & $0.00000^{*}$ \\
TBR does not Granger Cause RGDP & 40 & 0.72090 & 0.40162 \\
RGDP does not Granger Cause TBR & & 8.13991 & 0.00722 \\
\hline
\end{tabular}

Note: Sample: 1970 - 2010: (RGDP, LR, TR, GE, TBR)

Lags: 1

*sig. at $5 \%$

Source: Author's Computation

The results of the pairwise granger causality test presented in both table $6 \mathrm{a}$ and $6 \mathrm{~b}$ above showed the log and non $\log$ form of the data revealed that tha causality between real gross domestic product and lending rate, government expenditure and treasure bill rate are all significant at $5 \%$.

\section{Discussions of Results}

The major of objective of this paper is to investigate whether there is a long run relationship between monetary and fiscal policy and economic growth in Nigeria. Secondly and auxiliary to the above, the paper sought to examine the direction of causality between monetary and fiscal policy changes and economic growth employing the method of Johansen co-integration and the Granger causality tests using data spanning the period 1970-2010. The absence of consensus in the literature of financial economics with respect to the nature and degree of relationship between monetary and fiscal policy and economic growth as well as the controversy surrounding the direction of causality between these two variables provide a compelling motivation to examine specifically the monetary and fiscal changes-economic growth nexus within the Nigerian context.

With respect to the level and series regression, the results show that the Government expenditure (GE) is positively and significantly related lo GDP while the degree of openness of the economy (open) and degree of government regulation (pol) impact negatively and significantly on GDP. Lending rate (LR), government expenditure (GE), tax rate (TR) is not significant explanatory variables in the model. Overall, the level series multiple regression shows a high R2 of $99.37 \%$, an adjusted R2 of $99.17 \%$ and a D-W statistic of 1.89 (very close to 2.00). However, given the non-stationary feature of the Ievel series data, the application of the ADF and PP unit root tests indicate that the series are an integrating I (1) process. The Johansen co-integration test conducted indicates the existence of 6 co-integrating equations in the model meaning that there exists a long-run relationship among the variables. 
The results of the parsimonious error correction model show the short-run dynamic adjustment of the variables in the second difference model. The one-period lag of treasury bill rate and tax rate (at $10 \%$ ) and the degree of government regulation are significantly associated with changes in economic growth. This means that an increase in the treasury bill rates significantly increases GDP just as a substantial dismantling of government regulation (decrease in POL) significantly leads to improvements in GDP as presented in Table 4. The error correction variable (ICM) is appropriately signed significant and demonstrates that approximately $47.9 \%$ of disequilibrium in the model is corrected bi-annually by changes in the explanatory variables.

With respect to the direction of causality between monetary and fiscal policy indicators of performance and GDP, the Granger causality tests provide mixed results as shown in Tables 6A and 6B. Using lending rates (LR), Government expenditure (GE) and treasury bill rates (TBR) as indicators of monetary and fiscal policy, causality runs uni-directionally from GDP.s

However, the study review that there is significant relationship between monetary and fiscal policy and the Nigeria Gross Domestic Product (G.D.P). Therefore, monetary and fiscal policies are not monetary aggregates but the aggregates of the real sector of the economy. Monetary and fiscal policies are use by government to achieve price stability, exchange rate stability, maintenance of balance of payment, achievement of high level of employment and the promotion of an accelerated economic growth and development. Thus the monetary and fiscal policies are used to influence the various aggregate in the real other to achieve economic growth and development. Hence, for government to achieve their objective of economic growth and development the following monetary policy instruments are used (a) The portfolio constraint technique and the market intervention mechanism otherwise known as direct and indirect control. While on the other hand the instrument used as taxation and government expenditure.

\section{Conclusions}

This study so far has investigated the impact of monetary and fiscal policies actions on the growth and development of Nigerian economy. It has shown that monetary and fiscal favour economic growth and development. Hence, monetary and fiscal policy can be used to influence the Gross Domestic Product.

Monetary and fiscal policy are major economic stabilization weapons which involve measure designed to regulate and control the volume cost, availability and the direction of money and credit and the raising of revenue through taxation and other means, deciding on the level and pattern of expenditure for the purpose of influencing economic activities. The monetary and fiscal policies to be effective, it must affect spending decisions, but the chain of causation from given policy action to its impact on aggregate demand is circuitous and indirect and the speed of transmission may not be rapid. Therefore, policy makers need to select some proxy for the ultimate goal variable with the idea that by forcing the proxy or target variable to move in a given direction. Despite the numerous advantages of monetary and fiscal policies, their formulation and implementation matters a lot. However, in Nigeria monetary and fiscal policies have undergone many changes. Hence, they have not been fully utilized in achieving all their objectives.

\section{References}

Adekanya, F. (1983). The Element of Banking in Nigeria (3rd ed.). Lagos: F \& A Publishers Ltd.

Adewunmi \& Ojo. (1982). Banking and Finance in Nigeria. Benin, Nigeria: Graham Burn Publisher.

Anyanwu, J. C. (1993). Monetary Economics: Theory, Policy and Institutions. Nigeria: Hybrid Publishers Ltd.

Ayo, E. J. (1988). Money and Banking: Analysis and Policy in the Nigeria Context. Nigeria: George Allen and Union Publishers.

Central Bank of Nigeria. Annual Reports and Statement of Accounts for 1995-2004. Retrieved from http://www.cenbank.org/out/publications/reports/rd/2005/arp-2004-part1.pdf

Diulio, E. A. (1974). Theory and Problems of Macro-Economic Theory. New York: Mc Graw Hill book Company. Retrieved from http://www.universityofcalicut.info/syl/SDEBAEconomics.pdf

Furness, E. (1975). Money and credit in Developing Africa. New York: Macmillian Press Ltd.

Iyoha et al. (2003). An Introduction to Modern Macroeconomics (Revised Edition). University of Benin, Nigeria: Mindex Publishers.

Jhingan, M. L. (1977). Monetary Theory. Delhi: konark Publishers PVT Ltd.

Nwankwo, G. O. (1980). The Nigeria Financial System. London: Macmillan Press Ltd.

Nzotta, S. M. (2004). Money, Banking and Finance Theory and Practice. Owerri, Abuja, Lagos. 
Ojo, M. O. (1992). Monetary Policy in Nigeria in 1980s and prospects in the 1990s. CBN Economic and Financial Review, 30(1). Retrieved from http://www.valuefronteiraonline.com/public_upload/file/Wp68.pdf Olalusi, F. (1987). Introduction to Banking. Lagos, Nigeria: Evans Brother Ltd.

Olashore, O. (1988). Perspectives on Finance: Banking and Economic Policy in Nigeria. Nigeria: Heinemann Educational books Ltd.

Umoh, P. (1986). Monetary and Banking System in Nigeria. Nigeria: Adi Publishers. 